\title{
Procalcitonin as a potent marker of bacterial infection in febrile Afro-Caribbean patients at the emergency department
}

\author{
M. Limper • M. D. de Kruif • N. E. Ajubi • \\ A. P. van Zanten - D. P. M. Brandjes - A. J. Duits • \\ E. C. M. van Gorp
}

Received: 28 September 2010 / Accepted: 23 December 2010 /Published online: 19 May 2011

(C) The Author(s) 2011. This article is published with open access at SpringerLink.com

\begin{abstract}
Procalcitonin (PCT) has been shown to be of additional value in the work-up of a febrile patient. This study is the first to investigate the additional value of PCT in an Afro-Caribbean febrile population at the emergency department (ED) of a general hospital. Febrile patients were included at the ED. Prospective, blinded PCT measurements were performed in patients with a microbiologically or serologically confirmed diagnosis or a strongly suspected diagnosis on clinical grounds. PCT analysis was performed in 93 patients. PCT levels differentiated well between
\end{abstract}

M. Limper $(\bowtie) \cdot$ M. D. de Kruif • D. P. M. Brandjes •

E. C. M. van Gorp

Department of Internal Medicine, Slotervaartziekenhuis,

Louwesweg 6,

1066 EC Amsterdam, The Netherlands

e-mail: maarten.limper@slz.nl

M. Limper · A. J. Duits

Immunology Laboratory Department,

Red Cross Blood Bank Foundation,

Pater Euwensweg 36,

Willemstad, Curaçao, Netherlands Antilles

N. E. Ajubi

Department of Clinical Chemistry, St. Elisabeth Hospital, Breedestraat $193(\mathrm{O})$,

Willemstad, Curaçao, Netherlands Antilles

A. P. van Zanten

Department of Clinical Chemistry, Slotervaartziekenhuis, Louwesweg 6,

1066 EC Amsterdam, The Netherlands

E. C. M. van Gorp

Department of Virology, Erasmus Medical Center,

Dr. Molewaterplein 50,

3015 GE Rotterdam, The Netherlands confirmed bacterial and confirmed viral infection (area under the curve [AUC] of 0.82 , sensitivity $85 \%$, specificity $69 \%$, cut-off $0.24 \mathrm{ng} / \mathrm{mL}$ ), between confirmed bacterial infection and non-infectious fever (AUC of 0.84 , sensitivity $90 \%$, specificity $71 \%$, cut-off $0.21 \mathrm{ng} / \mathrm{mL}$ ) and between all bacterial infections (confirmed and suspected) and noninfectious fever (AUC of 0.80 , sensitivity $85 \%$, specificity $71 \%$, cut-off $0.21 \mathrm{ng} / \mathrm{mL}$ ). C-reactive protein (CRP) levels were shown to be less accurate when comparing the same groups. This is the first study showing that, in a nonCaucasian febrile population at the ED, PCT is a more valuable marker of bacterial infection than CRP. These results may improve diagnostics and eventually decrease antibiotic prescriptions in resource-limited settings.

\section{Introduction}

Infectious diseases are a major cause of morbidity and mortality worldwide, particularly in tropical regions [1-3]. Traditionally, fever has been associated with bacterial infection. However, in up to $50 \%$ of febrile people, fever is caused by non-bacterial infection or other inflammatory conditions, such as malignancy or auto-immune disease $[4,5]$. Because untreated bacterial infections may result in serious complications, the majority of patients with fever receive antibiotic treatment, leading to the overprescription of antibiotics and contributing to the development of antimicrobial resistance, increasing costs and possible adverse effects [6].

Neither clinical signs and symptoms, nor current biomarkers such as C-reactive protein (CRP) have, as a single marker, sufficient power to discriminate the aetiology of fever [7-9]. Lately, procalcitonin (PCT) has been added 
to the diagnostic work-up of febrile patients. Levels of PCT, a prohormone of calcitonin normally produced by the thyroid in physiological conditions, rise dramatically during bacterial infection, whereas low levels are detected during viral infections or non-infectious febrile conditions [10-13]. Both the diagnostic and prognostic properties of PCT have been shown to be superior to CRP in numerous studies [11, 13-16].

PCT is (still) relatively expensive, which limits its application in resource-poor settings in tropical regions where infectious diseases are widely prevalent. Since antibiotic overuse also tends to be a large problem in these regions, improvement of the diagnostic work-up of fever is required here in particular. Unfortunately, research on PCT has almost exclusively focused on Caucasian populations in Northern countries. As such, it is difficult to apply these results directly to patients in tropical regions with different disease spectra and different genetic backgrounds.

Therefore, this study aims to investigate the diagnostic and prognostic value of PCT and CRP in an AfroCaribbean febrile population at the emergency department (ED) of a general hospital.

\section{Materials and methods}

Study design and patients

The study was conducted at the ED of the St. Elisabeth Hospital, Curaçao, Netherlands Antilles, and was designed as a single-centre, observational cohort study. The study was approved by the local ethics committee for human studies. Written informed consent was obtained from all patients.

Between March 2008 and September 2009, all patients with fever (rectal $\mathrm{T}>38.5^{\circ} \mathrm{C}$ ) were included within $24 \mathrm{~h}$ after admission. Clinical data were registered, routine laboratory measurements were performed and cultures were taken. The patient follow-up was 60 days.

Supplementary diagnostics were ordered by the attending physician. At the St. Elisabeth Hospital, bacterial diagnostics (i.e. cultures of body fluids and faeces) can be ordered routinely; viral diagnostics are limited to serology only. Regular imaging by means of X-ray, computed tomography (CT) and magnetic resonance imaging (MRI) can be performed. No nuclear imaging can be performed.

\section{Definitions}

Final diagnoses were made at discharge by an independent physician and again in retrospect by the main investigator, using all of the available data, including culture results, serology, radiology and pathology data. In the case of a discrepancy between discharge diagnosis and the diagnosis in retrospect, an independent senior internist was asked to give a final clinical diagnosis.

When a causative bacterium or virus could be identified, either by culture or viral serology, in concordance with patient history and clinical signs and symptoms, patients were assigned to the 'confirmed bacterial' or 'confirmed viral' groups. Confirmed parasites and fungi were classified as 'confirmed infectious - other'.

When a specific micro-organism could not be identified, but clinical signs and symptoms were consistent with radiological or pathology findings - for instance, a clear history of fever, productive cough and dyspnoea, abnormal pulmonary auscultation and an infiltrate on the X-thorax-a clinical diagnosis was assigned and patients were assigned to the 'suspected bacterial' group or the 'suspected viral' group. Patients who were discharged without a clearinfectious or non-infectious - diagnosis were included in the 'rest' group. When a non-infectious cause of fever, without the presence of pathogenic micro-organisms, could be identified, patients were confined to the 'non-infectious' group.

\section{Measurements}

Blood samples were obtained by venapuncture at inclusion. Samples were centrifuged within $15 \mathrm{~min}(2 \times$ $4,000 \mathrm{rpm}$ at $4^{\circ} \mathrm{C}$ for $10 \mathrm{~min}$ ), aliquoted in $1-\mathrm{mL}$ portions and stored at $-70^{\circ} \mathrm{C}$. The blood was routinely analysed for haematological and biochemical variables, including CRP. Leukocyte count and differential was performed on the Siemens ADVIA 120 haematology analyser, using light scatter, differential white blood cell (WBC) lysis and myeloperoxidase staining to determine WBC parameters. CRP measurements were performed on the Abbott c8000 chemistry analyser using a latexenhanced immunoturbidimetric method. Prospective, blinded PCT measurements were performed by using a time-resolved amplified cryptate emission (TRACE) technology assay (Kryptor PCT, Brahms, Hennigsdorf, Germany) in those patients assigned to the 'confirmed bacterial', 'confirmed viral', 'confirmed infectious - other' , 'suspected bacterial', 'suspected viral' and 'non-infectious' groups.

All samples were measured in a blinded fashion without knowledge of the clinical status of the subjects.

Data analysis

Data were analysed using SPSS version 17.0. Data are presented as numbers with percentages or as medians with corresponding interquartile ranges (IQRs). Associations between the presence and absence of bacterial infection 
and levels of PCT, CRP and leukocytes were quantified using logistic regression analysis and are expressed as odds ratios (ORs) with 95\% confidence intervals (CIs) and $p$ values. Areas under the curve (AUC) of the receiver operating characteristic (ROC) curve were calculated. A $p$-value $<0.05$ was considered to be statistically significant.

\section{Results}

Patients

During the study period, 462 patients with fever were identified. In 120 patients (94\% Afro-Caribbean), a confirmed or strongly suspected diagnosis could be established. Due to logistical problems-i.e. blood not processed or stored properly - PCT could not be measured in 27 of these patients. Analysis was performed in 93 patients. The patient characteristics are shown in Table 1. Sixty-seven patients $(72.0 \%)$ were hospitalised; of these patients, 13 patients $(14.0 \%)$ died within the follow-up period of 60 days (median 9 days after inclusions, IQR 2-31 days) and seven patients $(7.5 \%)$ were admitted to the intensive care unit.

The final diagnoses are given in Table 2. In 42 patients $(45.2 \%)$, bacterial infection was confirmed; in 26 patients $(28.0 \%)$, bacterial infection was suspected. In four patients $(4.3 \%)$, viral infection was confirmed; in 14 patients $(15.1 \%)$, viral infection was suspected. In eight patients $(8.6 \%)$, a non-infectious cause of fever was identified (three malignancy, two drug-induced fever, extrauterine gravidity, sickle cell crisis, anaphylaxis).
Table 2 Final diagnosis of patients $(n=93)$ presenting with fever to the emergency department

\begin{tabular}{ll}
\hline Diagnosis & $n$ \\
\hline Urinary tract infection & 21 \\
Bacterial pneumonia & 20 \\
Dengue fever & 9 \\
Skin infection & 7 \\
Bacterial sepsis, focus unknown & 6 \\
Diabetic foot & 3 \\
HIV & 3 \\
Bacterial meningitis & 2 \\
Central line sepsis & 2 \\
Viral gastro-enteritis & 2 \\
Pelvic inflammatory disease & 2 \\
Abscess & 1 \\
Viral pneumonia & 1 \\
Viral meningitis & 1 \\
Viral respiratory tract infection & 1 \\
Diverticulitis & 1 \\
Cholangitis & 1 \\
Bacterial gastro-enteritis & 1 \\
Influenza & 1 \\
Non-infectious fever & 1 \\
\hline
\end{tabular}

\section{Markers of infection}

The levels of PCT, CRP and leukocytes are shown in Fig. 1. The median PCT levels were $0.96 \mathrm{ng} / \mathrm{mL}$ (IQR $0.19-5.22 \mathrm{ng} / \mathrm{mL}$ ) in the overall cohort, $1.91 \mathrm{ng} / \mathrm{mL}$ (IQR

Table 1 Patient characteristics. Patient cohort of adults $(n=93)$ presenting with fever to the emergency department

\begin{tabular}{|c|c|c|c|c|}
\hline & All, $n=93 n(\%) /$ median (IQR) & $\begin{array}{l}\text { Bacterial infection, } \\
n=68 n(\%) / \text { median (IQR) }\end{array}$ & $\begin{array}{l}\text { No bacterial infection, } \\
n=25 n(\%) / \text { median (IQR) }\end{array}$ & $p$-value \\
\hline Age (years) & $56(36-72)$ & $62(43.5-73.5)$ & $36(28-53.8)$ & $<0.001$ \\
\hline Sex, male & $55(59.1)$ & $40(58.8)$ & $16(64.0)$ & NS \\
\hline Duration of fever before inclusion (days) & $0(0-1)$ & $0(0-1)$ & $0(0-1)$ & NS \\
\hline \multicolumn{5}{|l|}{ Clinical signs } \\
\hline Temperature $\left({ }^{\circ} \mathrm{C}\right)$ & $39.0(38.8-39.8)$ & $39.3(38.9-39.8)$ & $39.0(38.7-39.5)$ & NS \\
\hline Tachypnoea & $20(21.5)$ & $16(25.4)$ & $2(8.0)$ & $<0.01$ \\
\hline Tachycardia & $57(61.3)$ & $43(68.2)$ & $14(56.0)$ & NS \\
\hline Mean arterial blood pressure $(\mathrm{mmHg})$ & $110(97-127)$ & $111(98-127)$ & $107(97-125)$ & NS \\
\hline \multicolumn{5}{|l|}{ Laboratory values } \\
\hline CRP (mg \%) & $12.1(2.6-21.9)$ & $15.3(6.2-25.3)$ & $2.8(1.0-6.8)$ & $<0.001$ \\
\hline Leukocytes (giga/L) & $11.4(6.9-18.3)$ & $13.1(8.1-19.0)$ & $9.0(5.0-12.3)$ & NS \\
\hline PCT (ng/mL) & $0.96(0.21-5.16)$ & $1.91(0.32-8.73)$ & $0.19(0.12-0.66)$ & $<0.001$ \\
\hline \multicolumn{5}{|l|}{ Outcome } \\
\hline Mortality & $12(12.9)$ & $11(17.5)$ & $1(4.0)$ & $<0.001$ \\
\hline Hospitalisation & $66(71.0)$ & $49(77.8)$ & $18(72.0)$ & NS \\
\hline Duration of hospital stay (days) & $9(4-15)$ & $7(1-13)$ & $4(0-7)$ & 0.01 \\
\hline
\end{tabular}



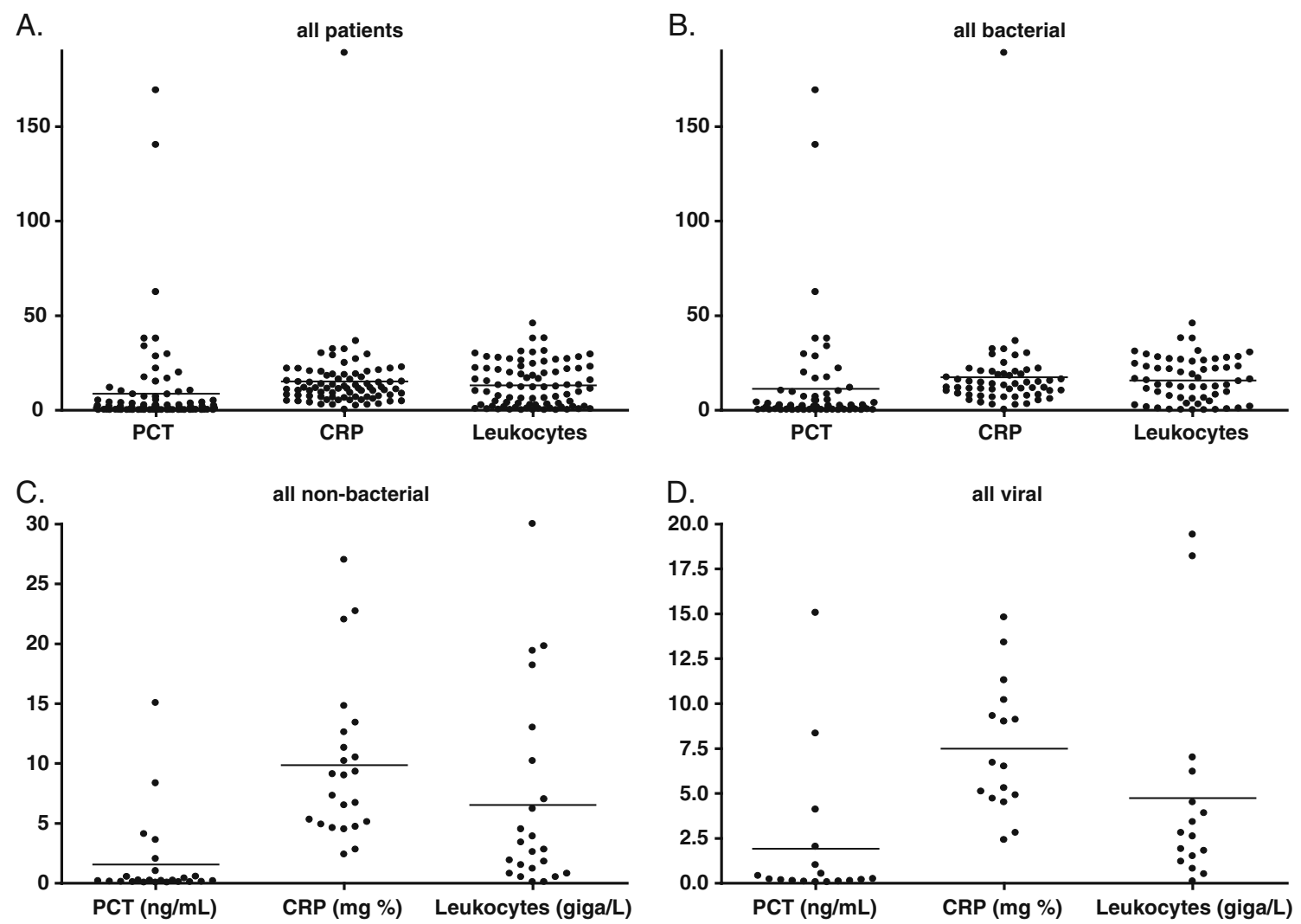

Fig. 1 Levels of C-reactive protein (CRP), procalcitonin (PCT) and leukocytes in patients presenting with fever to the emergency department. Panel A shows the levels of all patients together, panel B shows the levels

in patients with (confirmed or suspected) bacterial infection, panel $\mathrm{C}$ shows the levels in patients with non-bacterial fever and panel D shows the levels in patients with (confirmed or suspected) viral infection

$0.31-9.01 \mathrm{ng} / \mathrm{mL}$ ) in patients with confirmed and suspected bacterial infection and $0.22 \mathrm{ng} / \mathrm{mL}$ (IQR $0.11-1.52 \mathrm{ng} / \mathrm{mL}$ ) in patients with confirmed and suspected viral infection; the median CRP levels were $12.1 \mathrm{mg} \%$ (IQR 2.4-22.0 mg \%), $15.3 \mathrm{mg} \%$ (IQR 6.0-25.6 $\mathrm{mg} \%$ ) and $2.7 \mathrm{mg} \%$ (IQR 1.3$5.8 \mathrm{mg} \%$ ); and the median leukocyte levels were $11.4 \mathrm{giga} / \mathrm{L}$ (IQR 6.9-18.6 giga/L), $13.1 \mathrm{giga} / \mathrm{L}$ (IQR 8.0-19.7 giga/L) and $6.6 \mathrm{giga} / \mathrm{L}(\mathrm{IQR} 4.8-10.0 \mathrm{giga} / \mathrm{L}$ ) in the same groups, respectively.

\section{Diagnostic properties}

PCT levels differentiated well between infectious and noninfectious fever (AUC of 0.76 , sensitivity $78 \%$, specificity $71 \%$, cut-off $0.21 \mathrm{ng} / \mathrm{mL}$; Fig. 2), between confirmed bacterial and confirmed viral infection (AUC of 0.82 , sensitivity $85 \%$, specificity $69 \%$, cut-off $0.24 \mathrm{ng} / \mathrm{mL}$ ), between confirmed bacterial infection and non-infectious fever (AUC of 0.84 , sensitivity $90 \%$, specificity $71 \%$, cutoff $0.21 \mathrm{ng} / \mathrm{mL}$ ) and between all bacterial infections (confirmed and suspected) and non-infectious fever (AUC of 0.80 , sensitivity $85 \%$, specificity $71 \%$, cut-off $0.21 \mathrm{ng} / \mathrm{mL}$; Fig. 3). CRP levels were shown to be less accurate when comparing the same groups (AUC of 0.69 ,

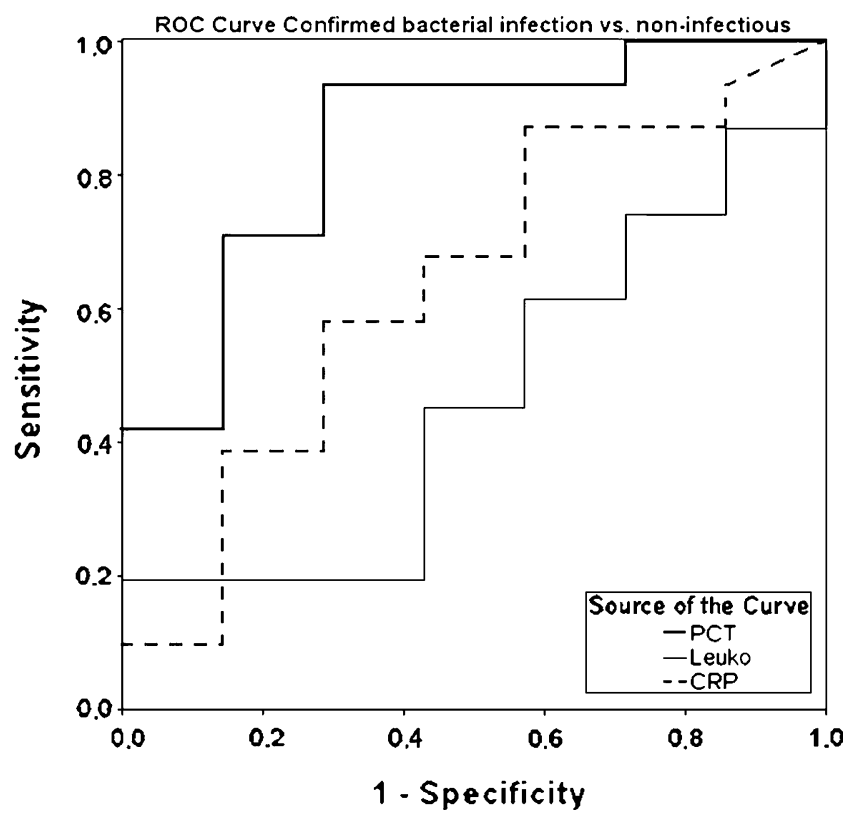

Fig. 2 Receiver operating characteristic (ROC) curve showing the diagnostic value of CRP, leukocytes and PCT for the differentiation between infectious fever and non-infectious fever. Area under the curve (AUC) for PCT 0.76 (sensitivity $78 \%$ /specificity $71 \%$ at cut-off $0.21 \mathrm{ng} / \mathrm{mL})$; CRP $0.59(88 \% / 43 \%$ at $0.85 \mathrm{mg} \%)$; leukocytes 0.41 $(10 \% / 100 \%$ at $28.0 \mathrm{giga} / \mathrm{L})$, respectively 


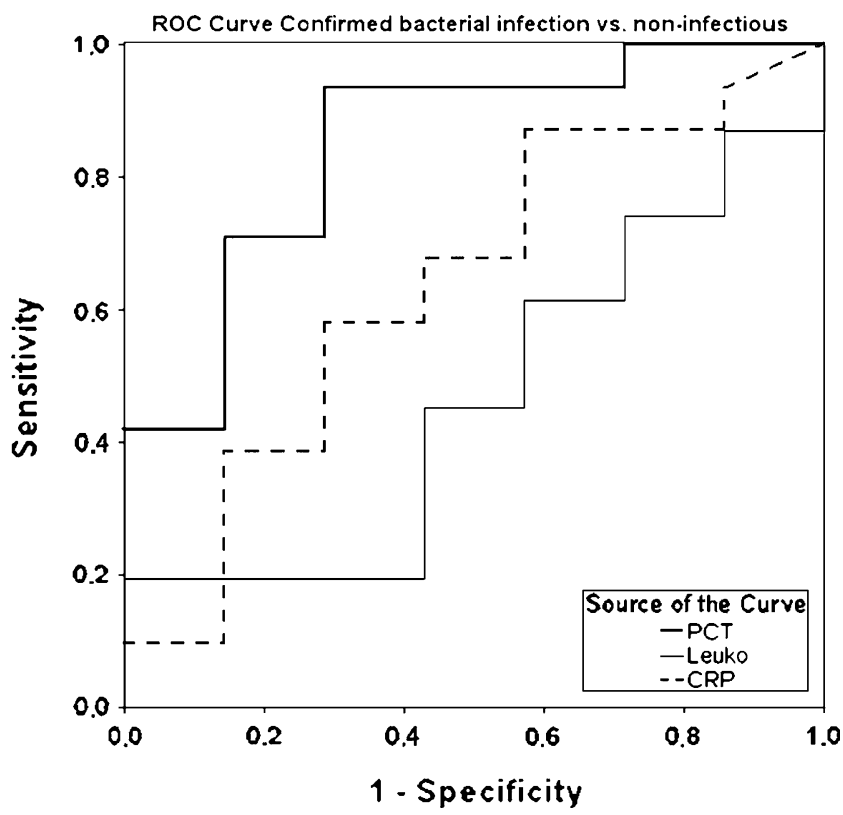

Fig. 3 ROC curve showing the diagnostic value of CRP, leukocytes and PCT for the differentiation between confirmed bacterial infection and non-infectious fever. AUC PCT 0.84 (sensitivity 90\%/specificity $71 \%$ at cut-off $0.21 \mathrm{ng} / \mathrm{mL})$; CRP $0.65(89 \% / 43 \%$ at $0.85 \mathrm{mg} \%)$; leukocytes $0.48(18 \% / 100 \%$ at $28.0 \mathrm{giga} / \mathrm{L})$, respectively

sensitivity $71 \%$, specificity $75 \%$, cut-off $8.3 \mathrm{mg} \%$; AUC of 0.65 , sensitivity $89 \%$, specificity $43 \%$, cut-off $8.5 \mathrm{mg}$ $\%$; AUC of 0.64 , sensitivity $90 \%$, specificity $43 \%$, cut-off $8.5 \mathrm{mg} \%$, respectively).

\section{Prognostic properties}

A significant correlation between PCT levels and confirmed bacterial infection was observed (OR 1.088; 95\% CI 1.018$1.162 ; p=0.013)$. A less strong but still significant correlation between CRP levels and confirmed bacterial infection could be found (OR 1.046; 95\% CI 1.004-1.090; $p=0.03)$. Leukocyte levels did not correlate with bacterial infection (OR 1.043; 95\% CI 0.986-1.104; $p=0.14$ ).

\section{Discussion}

In this study, we investigated the diagnostic and prognostic value of PCT and CRP in the diagnostic work-up of febrile patients at the ED of a general Caribbean hospital. Levels of PCT showed better diagnostic and prognostic properties than CRP. This is the first study to show that, in a nonCaucasian febrile population at the ED, PCT is a more valuable marker of bacterial infection than CRP.

It has recently been shown in many studies that inter- and intra-racial genetic polymorphisms of inflammatory genes, including polymorphisms in the CRP complex, are wide- spread and strongly influence the inflammatory response and the susceptibility to infectious diseases [17, 18]. Our study suggests that, regardless of multiple differences between genetic backgrounds and the different disease spectra, the positive results of PCT studies in Northern, Caucasian populations can likely be applied to an Afro-Caribbean population in a tropical region.

The relatively high costs of PCT measurements discourage the application of PCT in resource-poor settings. Furthermore, the PCT test is not readily available on most routine clinical chemistry analysers. However, an improved diagnostic work-up of fever is likely to result in a decreased use of antibiotics, which will not only limit the costs of the drugs themselves, but also side-effect-related costs. In the long term, increased costs due to antibiotic resistance are avoided. Indeed, studies have shown that the use of a PCTbased algorithm reduced the use of antibiotics in a general practice setting [11]. Moreover, recent studies have demonstrated that single PCT measurements may also be used to safely guide the duration of antibiotic therapy. In the landmark ProHOSP trial, a large trial investigating 1,359 patients with lower respiratory tract infections, a PCT-based algorithm significantly reduced the duration of antibiotic therapy, as well as frequencies of antibiotic sideeffects and duration of stay in the hospital [13]. Although no cost-effectiveness analysis was carried out, costs were obviously reduced this way.

Some limitations concerning this study have to be noted. First, the study was an observational study, thus, providing weaker empirical evidence than a randomised controlled study would provide. Also, in many febrile patients, no definite diagnosis could be established and PCT was not measured. This may have caused some selection bias; it could be suggested that patients with a clear diagnosis were more severely ill, resulting in more aggressive diagnostic procedures. This may explain the very high AUCs in this study, assuming that, in more severely ill subjects, the acute phase reaction is activated more significantly in case of a bacterial infection. Nevertheless, the primary aim of our study was to compare PCT and CRP within the same study subjects. In addition, diagnostic possibilities in Curaçao are relatively limited. Viral diagnostics generally only consist of serology with emphasis on Dengue fever; polymerase chain reaction (PCR) is not used routinely. Therefore, our study may underestimate the presence of viral disease, which may have influenced overall outcomes.

In conclusion, PCT is a valuable marker of bacterial infection in Afro-Caribbean febrile patients at the ED, with greater predictive value than CRP and other markers of infection. By implementing PCT as a routine marker in the work-up of febrile patients, the diagnostic power will be improved. This may eventually lead to a reduction in antibiotic prescriptions, costs and adverse events. 
Conflict of interest The authors declare that they have no conflict of interest.

Open Access This article is distributed under the terms of the Creative Commons Attribution Noncommercial License which permits any noncommercial use, distribution, and reproduction in any medium, provided the original author(s) and source are credited.

\section{References}

1. Martin GS, Mannino DM, Eaton S, Moss M (2003) The epidemiology of sepsis in the United States from 1979 through 2000. N Engl J Med 348:1546-1554

2. Nawar EW, Niska RW, Xu J (2007) National Hospital Ambulatory Medical Care Survey: 2005 emergency department summary. Adv Data 29:1-32

3. Reddy EA, Shaw AV, Crump JA (2010) Community-acquired bloodstream infections in Africa: a systematic review and metaanalysis. Lancet Infect Dis 10:417-432

4. Circiumaru B, Baldock G, Cohen J (1999) A prospective study of fever in the intensive care unit. Intensive Care Med 25:668-673

5. Kokturk N, Demir N, Oguzulgen IK, Demirel K, Ekim N (2005) Fever in pulmonary embolism. Blood Coagul Fibrinolysis 16:341-347

6. Macfarlane J, Lewis SA, Macfarlane R, Holmes W (1997) Contemporary use of antibiotics in 1089 adults presenting with acute lower respiratory tract illness in general practice in the U.K.: implications for developing management guidelines. Respir Med 91:427-434

7. Marnell L, Mold C, Du Clos TW (2005) C-reactive protein: ligands, receptors and role in inflammation. Clin Immunol 117:104-111

8. Meisner M (2005) Biomarkers of sepsis: clinically useful? Curr Opin Crit Care 11:473-480
9. Pepys MB, Hirschfield GM (2003) C-reactive protein: a critical update. J Clin Invest 111:1805-1812

10. Assicot M, Gendrel D, Carsin H, Raymond J, Guilbaud J, Bohuon C (1993) High serum procalcitonin concentrations in patients with sepsis and infection. Lancet 341:515-518

11. Briel M, Schuetz P, Mueller B, Young J, Schild U, Nusbaumer C et al (2008) Procalcitonin-guided antibiotic use vs a standard approach for acute respiratory tract infections in primary care. Arch Intern Med 168:2000-2007

12. Limper M, de Kruif MD, Duits AJ, Brandjes DP, van Gorp EC (2010) The diagnostic role of procalcitonin and other biomarkers in discriminating infectious from non-infectious fever. J Infect 60:409-416

13. Schuetz P, Christ-Crain M, Thomann R, Falconnier C, Wolbers M, Widmer I et al (2009) Effect of procalcitonin-based guidelines vs standard guidelines on antibiotic use in lower respiratory tract infections: the ProHOSP randomized controlled trial. JAMA 302:1059-1066

14. Chirouze C, Schuhmacher H, Rabaud C, Gil H, Khayat N, Estavoyer JM et al (2002) Low serum procalcitonin level accurately predicts the absence of bacteremia in adult patients with acute fever. Clin Infect Dis 35:156-161

15. de Kruif MD, Limper M, Gerritsen H, Spek CA, Brandjes DP, ten Cate $\mathrm{H}$ et al (2010) Additional value of procalcitonin for diagnosis of infection in patients with fever at the emergency department. Crit Care Med 38:457-463

16. Simon L, Gauvin F, Amre DK, Saint-Louis P, Lacroix J (2004) Serum procalcitonin and C-reactive protein levels as markers of bacterial infection: a systematic review and meta-analysis. Clin Infect Dis 39:206-217

17. Kathiresan S, Larson MG, Vasan RS, Guo CY, Gona P, Keaney JF Jr et al (2006) Contribution of clinical correlates and 13 C-reactive protein gene polymorphisms to interindividual variability in serum C-reactive protein level. Circulation 113:1415-1423

18. Khor CC, Vannberg FO, Chapman SJ, Guo H, Wong SH, Walley $\mathrm{AJ}$ et al (2010) CISH and susceptibility to infectious diseases. N Engl J Med 362:2092-2101 